\title{
Dinâmicas Econômicas Contemporâneas: uma Perspectiva geográfica
}

Pierre Alves Costa e Sandra Lúcia Videira Góis

\section{Q OpenEdition \\ 12 Journals}

Edição electrónica

URL: http://journals.openedition.org/espacoeconomia/10044

DOI: 10.4000/espacoeconomia.10044

ISSN: 2317-7837

Editora

Núcleo de Pesquisa Espaço \& Economia

Refêrencia eletrónica

Pierre Alves Costa e Sandra Lúcia Videira Góis, « Dinâmicas Econômicas Contemporâneas: uma Perspectiva geográfica », Espaço e Economia [Online], 16 | 2019, posto online no dia 06 janeiro 2020, consultado o 10 janeiro 2020. URL : http://journals.openedition.org/espacoeconomia/10044; DOI : 10.4000/espacoeconomia.10044

Este documento foi criado de forma automática no dia 10 janeiro 2020.

(c) NUPEE 


\section{Dinâmicas Econômicas Contemporâneas: uma Perspectiva geográfica}

Pierre Alves Costa e Sandra Lúcia Videira Góis

\section{Link para a Editora CRV:}

1 https://www.editoracrv.com.br/produtos/detalhes/34305-dinamicas-economicascontemporaneas-bruma-perspectiva-geografica

2 Editora: EDITORA CRV

3 ISBN:978-85-444-3599-1

4 DOI: $10.24824 / 978854443599.1$

5 Ano de edição: 2019 
Capa

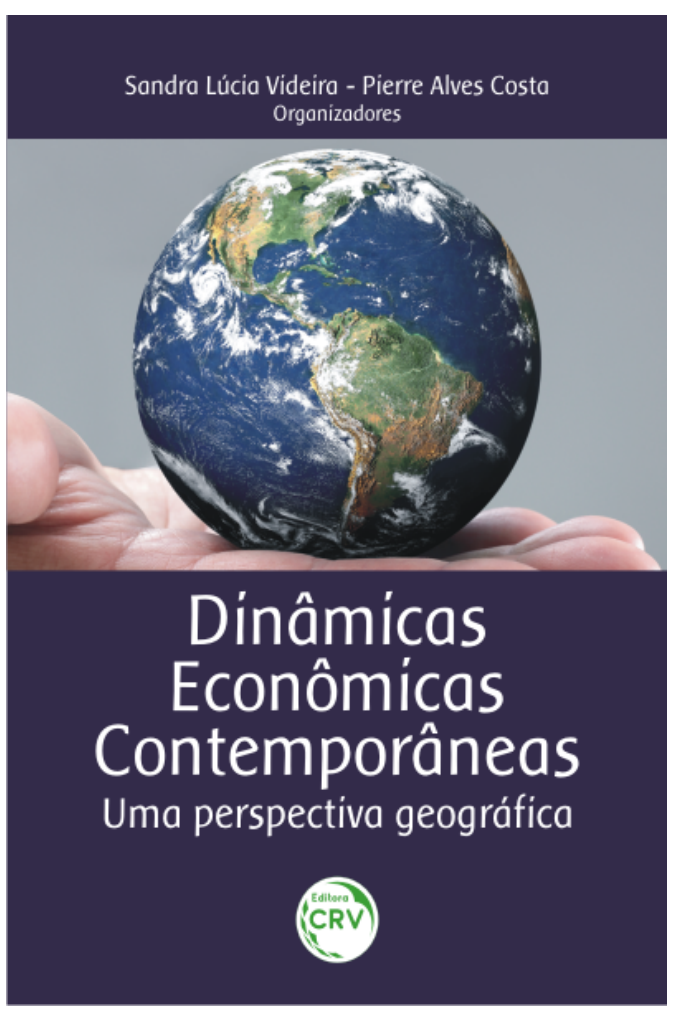

6 O livro intitulado Dinâmicas econômicas contemporâneas: uma perspectiva geográfica é resultado de dez anos de pesquisas, reunindo diversos geógrafos, com o propósito de ajudar a desvendar as principais transformações geoeconômicas das últimas três décadas (nas escalas local/regional/nacional) no território brasileiro.

O mundo e o Brasil vêm vivenciando profundas transformações econômicas desde 1973; ocasionando uma reestruturação produtiva-financeira-social e expressivos reflexos no território usado. Portanto, o desenvolvimento é cada vez mais desigual e geograficamente heterogêneo. Para compreendermos as características desse mundo contemporâneo, como: precarização do trabalho, uberização, intensificação da informatização, mundialização do capital; mecanização e robotização; financeirização da sociedade e do território; quarta revolução industrial; luta acirradíssima pelo controle das jazidas de petróleo entre outras; é fundamental o incentivo à pesquisa científica - elemento primordial para o desenvolvimento socioespacial de uma região ou pais.

Nesse contexto, o livro intitulado Dinâmicas Econômicas Contemporâneas: uma perspectiva geográfica é resultado de dez longos anos de pesquisas, reunindo diversos pesquisadores com o propósito de ajudar a desvendar as principais transformações geoeconômicas (nas escalas local / regional / nacional) no território brasileiro.

Esta obra não tem o intuito de finalizar as pesquisas e análises aqui presentes, mas, ao contrário, pretendemos que o livro seja um estímulo ao debate e às reflexões. Os autores - geógrafo e geógrafa - almejam valorizar as análises que compreendem o nosso vasto território, nas suas diversas escalas. Isso é fundamental diante da lógica de acumulação e reprodução do capital, da mundialização do capital e das reestruturações econômicas e, consequentemente, seus rebatimentos no território usado. 


\section{AUTORES}

\section{PIERRE ALVES COSTA}

Professor Associado da UNICENTRO-PR. Geógrafo e licenciado em Geografia pela UFF, Mestre em Geografia pela UFRJ e doutor em História pela UFF. Tem experiência na área de Geografia, com ênfase em Geografia Econômica, atuando principalmente nos seguintes temas: geografia urbanoindustrial, uso do território e dinâmica urbano-econômica, geo-história e história econômica.

\section{SANDRA LÚCIA VIDEIRA GÓIS}

Geógrafa pela FCT/UNESP, mestrado em Geografia pela UFSC e doutorado em Geografia pela FCT/ UNESP Presidente Prudente. Professora Associada da INICENTRO-Guarapuava-PR. Lider do Grupo de Pesquisa Estudos da Dinâmica Econômica (CNPq). Tem experiência na área de Geografia, com ênfase na Geografia Econômica, atuando principalmente nos seguinte temas: redes, urbano, rede bancária, bancos estrangeiros e internacionalização da economia brasileira. 